\title{
Copper Concentration of Vineyard Soils as a Function of pH Variation and Addition of Poultry Litter
}

\author{
Gilmar Ribeiro Nachtigall $^{1} *$, Roberta Corrêa Nogueirol $^{2}$, Luís Reynaldo Ferracciú Alleoni ${ }^{2}$ \\ and Michel Alexandro Cambri ${ }^{3}$ \\ ${ }^{1}$ Embrapa Uva e Vinho; Rua Livramento, 515; Conceição; Caixa Postal: 130; 95700-000; \\ gilmar@cnpuv.embrapa.br; Bento Gonçalves - RS - Brasil. ${ }^{2}$ Universidade de São Paulo; Escola Superior de \\ Agricultura Luiz de Queiroz - ESALQ/USP; Av. Pádua Dias, 11; Caixa Postal: 9; 13418-900; \\ rcnoguei@esalq.usp.br; Irfalleo@esalq.usp.br; Piracicaba - SP - Brasil. ${ }^{3}$ Engenheiro Agrônomo; Autônomo; Rod. \\ BR 010, km 1659; Caixa-Postal: 39; 68625-000; michel_cambri@yahoo.com.br - Paragominas - PA - Brasil
}

\begin{abstract}
Copper (Cu) concentration was evaluated as a function of $\mathrm{pH}$ variation and addition of poultry litter to a Dystrophic Lithic Udorthent and a Humic Dystrudept from the state of Rio Grande do Sul, Brazil, cultivated with vines treated with successive applications of $\mathrm{Cu}$-based product. Samples were collected from the surface layer (O to $10 \mathrm{~cm}$ ). Soluble Cu concentration was determined using DTPA and Mehlich III as extractants, and exchangeable Cu was determined in $\mathrm{CaCl}_{2}$. The availability of $\mathrm{Cu}$ was mainly affected by the soil $\mathrm{pH}$. CaCl $\mathrm{Catractant}_{2}$ had the best correlation with $\mathrm{Cu}$ concentration in contaminated soils, according to treatments applied. The addition of poultry litter did not reduce $\mathrm{Cu}$ availability in these soils. Total soil Cu content varied between 1,300 and 1,400 $\mathrm{mg} \mathrm{kg}^{-1} \mathrm{in}$ both soils. Copper available fractions, extracted by DTPA, CaCl $\mathrm{C}_{2}$ and Mehlich III, averaged 35, 0.2 and 63\%, respectively, of the total $\mathrm{Cu}$ present in the soil.
\end{abstract}

Key words: Vineyard soils, chemical extractors, $\mathrm{pH}$ and soil organic matter

\section{INTRODUCTION}

The continued use of some agricultural pesticides can lead to metals accumulation in the soil (López - Mosquera et al., 2000), contaminate the food chain and decrease crop yield (Obrador et al., 1997). Once heavy metals are persistent in the environment, they remain in the biosphere for long periods of time (Silveira et al., 2003). Deluisa et al. (1996), Flores Vélez (1996), Brun et al. (1998), and Pietrzak and McPhail (2004) described that the continuous use of $\mathrm{Cu}$-based fungicides to control vine diseases resulted in $\mathrm{Cu}$ accumulation on the soil surface. A significant portion of the $\mathrm{Cu}$ reaching the soil remained in the upper layers, mainly bound to organic matter (OM) (Brun et al., 1998).

In a study with 25 soil samples from land cultivated with vines in France, Brun et al. (1998) observed total $\mathrm{Cu}$ contents varying from 30 to 250 $\mathrm{mg} \mathrm{kg}^{-1}$, depending on the age of the vines, type of soil, and regional climate. Comparing various extractors on these soils, they observed that $\mathrm{Cu}$ extractable with $0.01 \mathrm{~mol} \mathrm{~L}^{-1} \mathrm{CaCl}_{2}$ correlated well with the soil $\mathrm{pH}$, (it decreased with increasing soil $\mathrm{pH}$ ), that is an important property controlling the bioavailability of $\mathrm{Cu}$, whereas $\mathrm{Cu}$ extractable by DTPA pH 7.3 correlated only with the CEC (it

\footnotetext{
${ }^{*}$ Author for correspondence
} 
decreased with increasing soil CEC). Soil OM concentration was relatively low and none of the extractors used in the study correlated well with this attribute. Brun et al. (2001) cultivated maize in vineyard soils with high $\mathrm{Cu}$ content and observed that $\mathrm{Cu}$ concentration in the upper part of the maize plant had a high negative correlation with $\mathrm{pH}$ and a high positive correlation with soil $\mathrm{OM}$, whereas CEC had a high positive correlation with $\mathrm{Cu}$ concentrations in the roots. $\mathrm{CaCl}_{2} 0.01$ mol L $\mathrm{L}^{-1}$ had a better correlation with $\mathrm{Cu}$ in the upper parts of the plant than DTPA, but the opposite occurred with $\mathrm{Cu}$ in the roots.

Data for total $\mathrm{Cu}$ content in Brazilian soils are scarce (Abreu et al., 2001a). Jackson (1964) described that total content values within the range 5 to $40 \mathrm{mg} \mathrm{kg}^{-1}$ for soils in tropical and temperate regions were considered normal, although in some soils it was as low as 2 and in others higher than $100 \mathrm{mg} \mathrm{kg}^{-1}$.

Mineral and organic soils can adsorb metals in differing intensities. $\mathrm{OM}, \mathrm{Fe}$ and $\mathrm{Al}$ oxyhydroxides and clay minerals are the main components of soils that influence sorption reactions (Barry et al., 1995). According to Silveira and Alleoni (2003), the charge balance in the soil, influenced by the levels of OM and clay and the mineralogical characteristics, particularly the iron and aluminum oxide and hydroxide contents, were the most important factors controlling $\mathrm{Cu}$ adsorption reactions in acric soils. Even at low concentrations in the soil, they could coat sand and clay mineral surfaces, influencing adsorption reactions.

The availability of heavy metals is relatively low at $\mathrm{pH} 6.5$ to 7 (Kabata-Pendias and Pendias, 1987). The mobility of the majority of heavy metals becomes limited as $\mathrm{pH}$ increases, due to the precipitation of insoluble forms as hydroxides, carbonates and organic complexes. As $\mathrm{pH}$ increases, the surface area of the negative charges on the colloid increases, enhancing the electrostatic attraction between the adsorbent and the metal (Sposito, 1989). As the CEC rises, the number of available adsorption sites on soil colloids increases to adsorb metallic cations.

Organometallic associations can occur in both solid and liquid phases of the soil. Copper complexes can be formed by dissolved organic carbon (DOC), increasing the risk of leaching of the metal in the profile (Moolenaar and Beltrami,
1998). Humus and other organic compounds can chelate metals and form stable molecules altering their bioavailability.

The objective of this study was to assess the availability of $\mathrm{Cu}$ as a function of variation in $\mathrm{pH}$ and organic matter (OM) concentration in soils with high $\mathrm{Cu}$ content, assuming that available $\mathrm{Cu}$ concentration could increase as soil $\mathrm{pH}$ dropped and decreased as soil OM content increased.

\section{MATERIAL AND METHODS}

The study was carried out with samples from the surface layer $(0$ to $10 \mathrm{~cm})$ of a typical dystrophic Lithic Udorthent (LU) and a Humic Dystrudept (HD), collected from the farms located in Pinto Bandeira $\left(29^{\circ} 06^{\prime} \mathrm{S}\right.$ and $\left.51^{\circ} 27^{\prime} \mathrm{W}\right)$ and Bento Gonçalves (29 $10^{\prime} \mathrm{S}$ and $51^{\circ} 31^{\prime} \mathrm{W}$ ), in the Rio Grande do Sul highlands, Brazil. These soils had been cultivated for more than 15 years with vines (Isabel cultivar), receiving continuous applications of Cu-based phytosanitary products, mainly "calda bordaleza" (Bordeaux mixture) (approximately ten applications per year - approximately $65 \mathrm{~kg} \mathrm{ha}^{-1}$ of $\mathrm{Cu}$ per year). The chemical properties of $\mathrm{LU}$ and HD soils were: $\mathrm{pH}$ in $\mathrm{CaCl}_{2} 0.01 \mathrm{~mol} \mathrm{~L}^{-1}$ of $6.9 \mathrm{e}$ 6.4; $\mathrm{OM}$ of 85 and $94 \mathrm{~g} \mathrm{~kg}^{-1} ; 140$ and $170 \mathrm{mmol}_{\mathrm{c}}$ $\mathrm{dm}^{-3}$ of $\mathrm{Ca} ; 35$ and $39 \mathrm{mmol}_{\mathrm{c}} \mathrm{dm}^{-3}$ of $\mathrm{Mg} ; 5.4$ and $8.0 \mathrm{mmol}_{\mathrm{c}} \mathrm{dm}^{-3}$ of $\mathrm{K}$; and 193.4 and $230.0 \mathrm{mmol}_{\mathrm{c}}$ $\mathrm{dm}^{-3}$ for CEC. These soils had a high soluble $\mathrm{Cu}$ concentration in DTPA pH 7.3 (522 and $475 \mathrm{mg}$ $\mathrm{kg}^{-1}$ for LU and HD, respectively).

Two experiments were conducted under laboratory conditions: a) Variation in soil $\mathrm{pH}$ values - 50, $100,200,300$ and $400 \mathrm{mmol} \mathrm{kg}{ }^{-1}$ of $\mathrm{HNO}_{3}$ were applied to reduce $\mathrm{pH}$ values, since the $\mathrm{pH}$ for these soils was higher than 6.0. Samples were incubated close to the maximum water retention capacity, until the $\mathrm{pH}$ remained stable; b) Variation in soil $\mathrm{OM}$ concentration - rates equivalent to $10,20,40$ and $80 \mathrm{t} \mathrm{ha}^{-1}$ of poultry litter (dry basis) were applied; this material was frequently used by farmers. Samples $(1.0 \mathrm{~kg})$ were incubated for three months, with humidity close to the maximum water retention capacity. Poultry litter had a $\mathrm{C} / \mathrm{N}$ ratio of 15:1, 609 g.kg-1 compostable OM, and total $\mathrm{Cu}$ content of $518 \mathrm{mg} \mathrm{kg}$. The two experiments were set up in a randomized block design with four replications. After incubation, samples were dried at $45^{\circ} \mathrm{C}$ and passed through a $2.0 \mathrm{~mm}$ sieve. 
Sample $\mathrm{pH}$ was measured in $\mathrm{CaCl}_{2} 0.01 \mathrm{~mol} \mathrm{~L}^{-1}$ (1:2.5 soil:solution). Organic carbon concentration was determined after oxidation with potassium dichromate, in the presence of suphuric acid, and titration of excess dichromate with ammonium ferrous sulfate (Cantarella et al., 2001). Cu concentration was determined in DTPA $\mathrm{pH} 7.3$ (Abreu et al., 2001b), exchangeable $\mathrm{Cu}$ in $\mathrm{CaCl}_{2}$ $0.01 \mathrm{~mol} \mathrm{~L}^{-1}$ (Brun et al., 1998), and exchangeable $\mathrm{Cu}$ by Mehlich III (Mehlich, 1984). Total $\mathrm{Cu}$ was determined according to the US-EPA 3052 method, with microwave-assisted digestion with $\mathrm{HNO}_{3}+\mathrm{HF}+$ deionized water (United States, 1996).

Analysis of variance was used to evaluate the significance of the effects of treatments effects on soluble and exchangeable $\mathrm{Cu}$. Pairwise comparison methods was used to separate the extractor's means.

\section{RESULTS AND DISCUSSION}

\section{Variations in soil $\mathbf{p H}$ and $\mathrm{OM}$ contents}

Under uncultivated conditions (natural soil), Lithic Udorthents of the vine-growing region of the Serra Gaúcha were moderately acid (pH around 5.6 in water), whereas the Humic Dystrudepts were extremely acid ( $\mathrm{pH}$ around 4.1) (Flores et al., 1999). In such regions, lime was of common use, and $\mathrm{pH}$ was expected to increase up to 6.0. However, $\mathrm{pH}$ could be either reduced by the use of nitrogen-enriched fertilizers, such as ammonium sulfate, or it could be raised by the reapplication of lime, as cultivation progresses. The $\mathrm{pH}$ values dropped linearly from 7.0 to 3.8 as $\mathrm{HNO}_{3}$ doses were added around (Fig. 1). However, the doses of $\mathrm{HNO}_{3}$ did not alter the OM content (data not shown). Thus, the variation in $\mathrm{Cu}$ concentration was only due to $\mathrm{pH}$ variation.

In the wine-producing region of "Serra Gaúcha" the Inceptsols with humic characteristics were of common occurrence. These soils have an average organic carbon content (higher than $17.0 \mathrm{~g} \mathrm{~kg}^{-1}$ ) up to a depth of $90 \mathrm{~cm}$. On the other hand, Entisol, organic carbon content was lower (around $13.0 \mathrm{~g}$ $\mathrm{kg}^{-1}$ ) (Flores et al., 1999). The application of residues including poultry litter has been a common practice to increase soil OM content, and improve the soil's chemical and physical properties. The incubation with poultry litter resulted in a linear increase in OM concentration for both the soils, ranging from 85.3 (control) to
$105.0 \mathrm{~g} \mathrm{~kg}^{-1}$ (after addition of $80 \mathrm{t} \mathrm{ha}^{-1}$ of poultry litter) in the LU, and from 94.6 (control) to $103.0 \mathrm{~g}$ $\mathrm{kg}^{-1}$ (after addition of $80 \mathrm{tha}^{-1}$ of poultry litter) in the HD (Fig. 1).

\section{Effect of $\mathbf{p H}$ on soil copper concentrations}

As expected, $\mathrm{CaCl}_{2}-\mathrm{Cu}$ was higher at lower $\mathrm{pH}$ values (Fig. 2). There was a marked variation in $\mathrm{Cu}$ concentration at $\mathrm{pH}$ between 4 and 6 , which was the predominant $\mathrm{pH}$ range of these soils when lime was not applied. Brun et al. (1998) observed a negative linear relationship between $\mathrm{pH}$ and concentration of $\mathrm{Cu}$ extracted with $\mathrm{CaCl}_{2} \cdot \mathrm{Cu}$ concentrations increase as the soil $\mathrm{pH}$ dropped due to the dissolution of $\mathrm{Cu}$ insoluble composts at $\mathrm{pH}$ lower than 5. At $\mathrm{pH}$ values higher than $6, \mathrm{Cu}$ could be either adsorbed on the surfaces of $\mathrm{Fe}$ and $\mathrm{Al}$ oxides or precipitated in hydroxyl forms $(\mathrm{Cu}(\mathrm{OH}) n)$. Under these conditions, the number of binding sites of $\mathrm{Cu}$ with $\mathrm{OM}$ could also increase, and the stability of the bonding consequently increases the quantity of adsorbed $\mathrm{Cu}$ (Sims and Patrick, 1978). There was no significant correlation between $\mathrm{pH}$ value and Mehlich III-Cu concentration.

The decrease in the concentration of $\mathrm{Cu}$ soluble in DTPA pH 7.3 after $\mathrm{pH}$ decrease was unexpected (Fig. 2). Camargo et al. (1982), worked with soils in the State of São Paulo, Brazil, and found a negative correlation between $\mathrm{pH}$ and DTPAsoluble $\mathrm{Cu}$ concentration, suggesting that $\mathrm{Cu}$ availability dropped as $\mathrm{pH}$ increased. It was possible that the observed drop in DTPA $\mathrm{pH}$ 7.3extracted $\mathrm{Cu}$ concentration as a function of $\mathrm{pH}$ could have occurred due to the low efficiency of this extractor for these samples.

The stability of the DTPA boding to with $\mathrm{Cu}$ increased at $\mathrm{pH}$ higher than 7.0 (Norvell, 1991). Also, the $\mathrm{pH}$ of natural soil was 7.3, dropping to 5.8 at the highest dose of $\mathrm{HNO}_{3}$. DTPA was developed to evaluate the availability of micronutrients in soils with low concentrations of these elements. Hence, when DTPA was used in contaminated soil, high amount of metals could saturate the extraction capacity of the DTPA solution. Brun et al. (1998) also observed no relationship between $\mathrm{pH}$ and DTPA-Cu.

The DTPA extractor, originally developed by Lindsay and Norvell (1978) to predict availability of $\mathrm{Zn}, \mathrm{Fe}, \mathrm{Mn}$ and $\mathrm{Cu}$, and to identify soil deficiencies adversely affecting crop yield, is also used by many soil laboratories in Brazil. However, as suggested by Brun et al. (1998), under acidic 
conditions, DTPA might not be effective in assessing the bioavailability of $\mathrm{Cu}$, since the buffer capacity of the extractor could exceed. This could be explain the behavior observed in regard to $\mathrm{Cu}$ concentration measured using DTPA.

Mehlich III-Cu concentration were on average approximately twice DTPA-Cu concentration figures, and 300 times those obtained using $\mathrm{CaCl}_{2}$ in LU and HD soils (Fig. 2). This difference in extraction occurred because a significant part of the available $\mathrm{Cu}$ was chelated, and the extraction using a salt became more difficult (Stevenson, 1994). Comparing the $\mathrm{Cu}$ concentration found by Brun et al. (1998) in 25 vineyard soils, in the south of France, with that obtained in the two soils under investigation, it can be observed that the concentration values were much higher than those obtained in French vineyards, mainly at lower $\mathrm{pH}$ values, which was probably due to differences in the use of $\mathrm{Cu}$-based products in the vineyards, as well as the chemical properties of the soils. Copper concentration at low $\mathrm{pH}$ values highlighted the importance of correcting soil acidity to attenuate the phytotoxic effect of $\mathrm{Cu}$ on plants, minimizing contamination in vine production systems.

Total $\mathrm{Cu}$ content varied between 1,355 \pm 45 and $1,381 \pm 31 \mathrm{mg} \mathrm{kg}^{-1}$ for LU and HD soils, respectively. These values were higher than the results obtained by Brun et al. (1998), who observed total $\mathrm{Cu}$ content ranging from 30 to 250 $\mathrm{mg} \mathrm{kg}^{-1}$ in southern France. Also, Drouineau and Mazoyer (1962) and Flores Vélez (1996) showed values as high as 400 to $500 \mathrm{mg} \mathrm{kg}^{-1}$ total $\mathrm{Cu}$ in the vineyards of Alsace, Champagne and Burgundy, whereas Delas (1963) found up to 800 $\mathrm{mg} \mathrm{kg}^{-1}$ total $\mathrm{Cu}$ total in areas of Bordeaux. In Australia, Pietrzak and McPhail (2004), evaluated 14 vineyards cultivated from 20 to older than 90 years, observed total $\mathrm{Cu}$ content between 10 and $250 \mathrm{mg} \mathrm{kg}^{-1}$. The differences could be explained by climatic conditions in the Serra Gaúcha region, which required a higher number of applications of $\mathrm{Cu}$-based products to control disease and for the high original concentration of $\mathrm{Cu}$ of these soils originated of the basalt. Total $\mathrm{Cu}$ content in the cultivated soils of Serra Gaúcha vineyards exceeded the maximum concentration currently permitted by the European Community $(140 \mathrm{mg}$ $\mathrm{kg}^{-1}$ ) (CEC, 1986), which was worthy of attention owing to the possibility of contaminating the agricultural system. As expected, total $\mathrm{Cu}$ content was not affected by variations in soil $\mathrm{pH}$.
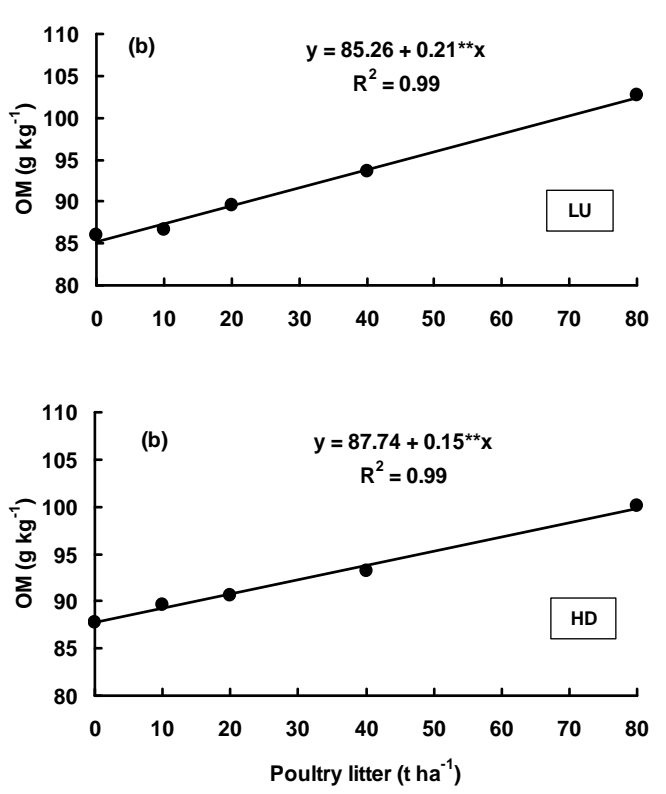

Figure 1 - Relationship between doses of $\mathrm{HNO}_{3}$ and $\mathrm{pH}$ (a) and between doses of poultry litter and organic matter concentration (b) in a typical dystrophic Lithic Udorthent (LU) and a Humic Dystrudept (HD) in the Rio Grande do Sul highlands, Brazil 

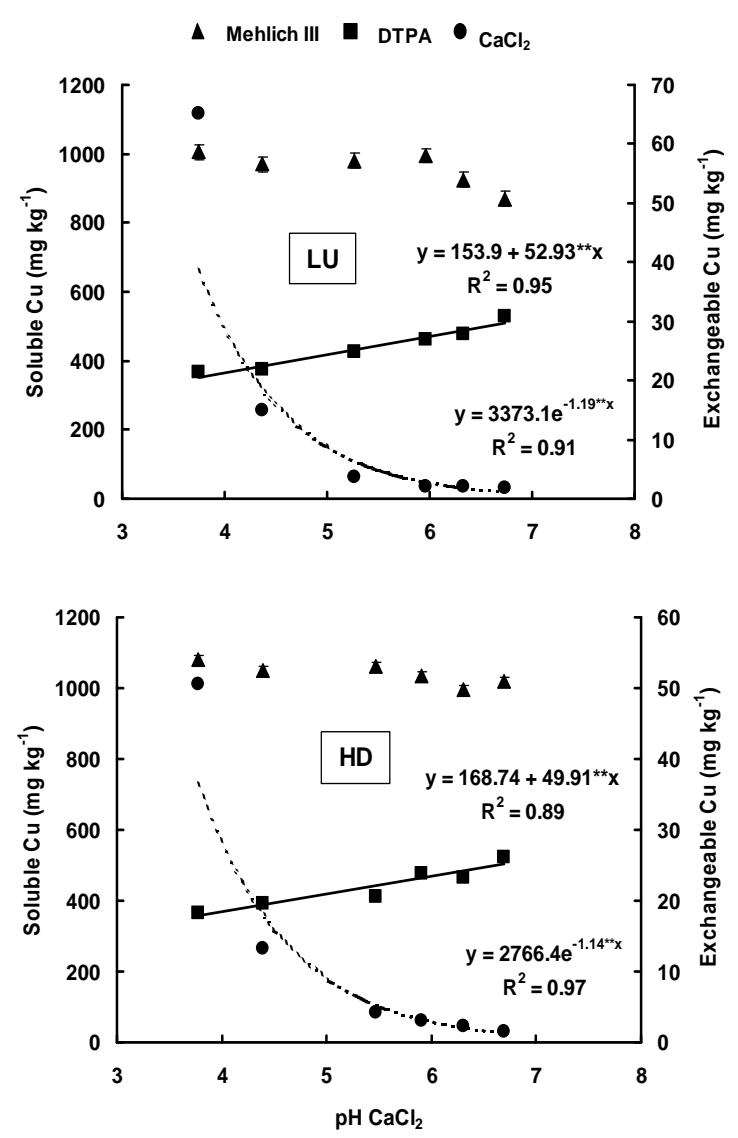

Figure 2 - Relationship between soil $\mathrm{pH}$ value in $\mathrm{CaCl}_{2}$ and soluble $\mathrm{Cu}$ concentration, extracted by DTPA and Mehlich III, and exchangeable $\mathrm{Cu}$ concentration, extracted by $\mathrm{CaCl}_{2}$, in a typical dystrophic Lithic Udorthent (LU) and a Humic Dystrudept (HD) in the Rio Grande do Sul highlands, Brazil

\section{Effect of addition of poultry litter on soil copper concentrations}

On average, Mehlich III-Cu concentration was around twice that of DTPA-Cu concentration, and 300 times higher than $\mathrm{CaCl}_{2} \mathrm{Cu}$ in $\mathrm{LU}$ and HD soils (Fig. 3), matching the proportions observed in the experiment assessing the effect of $\mathrm{pH}$. Total $\mathrm{Cu}$ content ranged from 1,201 \pm 17 and $1,274 \pm 18 \mathrm{mg} \mathrm{kg}^{-1}$ respectively for LU and HD soils. Since clay minerals and OM are the main components involved in $\mathrm{Cu}$ retention in the soil, it is expected that soils rich in $\mathrm{OM}$ or receiving applications of organic residues may retain high quantities of this element, $\mathrm{Cu}$ forming stable complexes with humic and fulvic acids, mainly due to the high concentration of functional groups with oxygen, such as carboxyls and phenols (Stevenson and Ardakani, 1972).

The expected reduction in $\mathrm{Cu}$ concentration accompanying a rise in $\mathrm{OM}$ concentration was not observed for $\mathrm{Cu}$ extracted by DTPA $\mathrm{pH} 7.3$ and Mehlich III (Fig. 3). This phenomenon indicated that the added OM was rapidly mineralized, adversely affecting the generation of organic complexes for the $\mathrm{Cu}$ retention. As these soils had a high OM concentration, it was probable that high proportions of total $\mathrm{Cu}$ were already retained in the soil's organic complexes, so that the small percentage of free $\mathrm{Cu}$ capable of retention by the organic matter did not alter the $\mathrm{Cu}$ concentration obtained using extractors. For vineyard soils with high OM concentration, the addition of organic residues probably did not 
contribute to reduce $\mathrm{Cu}$ availability. Conversely, for vineyard soils with low OM concentration, the addition of organic residues probably contributed to the higher retention of $\mathrm{Cu}$ came from the $\mathrm{Cu}$-based phytosanitory products. $\mathrm{CaCl}_{2}$-extracted $\mathrm{Cu}$ concentrations increased with the increase of $\mathrm{OM}$ concentration, which could be explained by the contribution of poultry litter in supplying $\mathrm{Cu}$, since total $\mathrm{Cu}$ reached 518 $\mathrm{mg} \mathrm{kg}{ }^{-1}$. Although there was a high bonding affinity between $\mathrm{Cu}$ and $\mathrm{OM}$, the absence of a relationship between these two variables was also observed by Brun et al. (1998).

No significant linear relationship was observed between total $\mathrm{Cu}$ content and the concentration of $\mathrm{Cu}$ extracted by DTPA, Mehlich III and $\mathrm{CaCl}_{2}$, as well as between the $\mathrm{Cu}$ concentrations for Mehlich III and $\mathrm{CaCl}_{2}$ extraction for both soils (Table 1), which was justified by the different principles of the extractors used to obtain the soluble $\mathrm{Cu}$ concentrations. The $\mathrm{Cu}$ extracted by DTPA had a negative relationship with $\mathrm{Cu}$ extracted using Mehlich III and $\mathrm{CaCl}_{2}$. Brun et al. (1998), working with 25 vineyard soils in France, observed significant linear correlation coefficients between total $\mathrm{Cu}$ and DTPA $\mathrm{Cu}$, but did not obtain significant relationship between Total $\mathrm{Cu}$ and $\mathrm{CaCl}_{2} \mathrm{Cu}$, and also for DTPA-Cu and $\mathrm{CaCl}_{2}-\mathrm{Cu}$.

Soil $\mathrm{pH}$ is the most important factor for $\mathrm{Cu}$ bioavailability (Gupta and Aten, 1993). Considering that the $\mathrm{Cu}$ concentration extracted by $0.01 \mathrm{~mol} \mathrm{~L}^{-1} \mathrm{CaCl}_{2}$ dropped suddenly with increased soil $\mathrm{pH}$, and assuming that DTPA was not very effective in predicting $\mathrm{Cu}$ availability at low $\mathrm{pH}, 0.01 \mathrm{~mol} \mathrm{~L}^{-1} \mathrm{CaCl}_{2}$ seemed to be the most appropriate $\mathrm{Cu}$ extraction method for $\mathrm{Cu}$ contaminated soils.

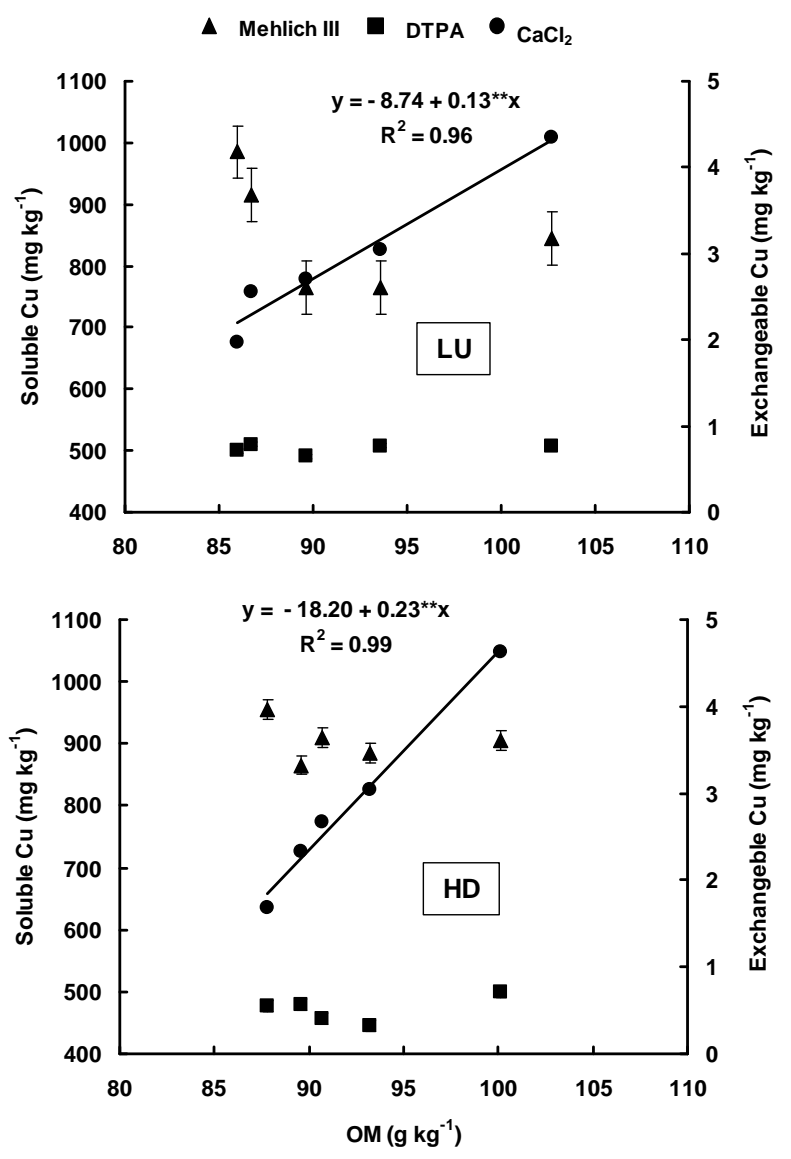

Figure 3 - Relationship between soil $\mathrm{OM}$ concentration and soluble $\mathrm{Cu}$ concentration, extracted by DTPA and Mehlich III, and exchangeable $\mathrm{Cu}$ concentration, extracted by $\mathrm{CaCl}_{2}$, in a typical dystrophic Lithic Udorthent (LU) and a Humic Dystrudept(HD) in the Rio Grande do Sul highlands, Brazil 
Table 1 - Linear correlation coefficients between total $\mathrm{Cu}$ and the different forms of $\mathrm{Cu}$ extractable from a typical dystrophic Lithic Udorthent (LU) and a Humic Dystrudept (HD) in the Rio Grande do Sul highlands, Brazil, as a function of variation in soil $\mathrm{pH}$ and $\mathrm{OM}$.

\begin{tabular}{lccc} 
& $\mathbf{C u}$ & $\mathbf{C u}_{\text {MTPA }}$ & $\mathbf{C u}_{\mathrm{CaCl}_{2}}$ \\
\hline $\mathrm{Cu}_{\text {Total }}$ & $-0.18^{\mathrm{NS}}$ & $0.22^{\mathrm{NS}}$ & $-0.32^{\mathrm{NS}}$ \\
$\mathrm{Cu}_{\text {DTPA }}$ & & $-0.57^{* *}$ & $-0.71^{* *}$ \\
$\mathrm{Cu}_{\text {Mehlich III }}$ & & & $0.38^{\mathrm{NS}}$ \\
\hline
\end{tabular}

\section{CONCLUSIONS}

- Cu concentration was mainly affected by soil pH. $0.01 \mathrm{~mol} \mathrm{~L}^{-1} \mathrm{CaCl}_{2}$ solution was the extractor resulting the best correlation with $\mathrm{Cu}$ concentration in contaminated soils;

- Application of poultry litter in the soils did not reduce their $\mathrm{Cu}$ concentration;

- Total $\mathrm{Cu}$ content varied between 1,200 and $1,380 \mathrm{mg} \mathrm{kg}^{-1}$ in both soils, exceeding the maximum permitted concentration currently imposed by the European Community (140 mg $\mathrm{kg}^{-1}$ );

- Available $\mathrm{Cu}$ fractions extracted by DTPA, $\mathrm{CaCl}_{2}$ and Mehlich III represented, on average, $35,0.20$ and $63 \%$, respectively of total $\mathrm{Cu}$ present in the soil, indicating that some $\mathrm{Cu}$ was present in other forms.

\section{RESUMO}

Avaliaram-se os teores de $\mathrm{Cu}$ em função da variação do $\mathrm{pH}$ e da adição de cama-de-frango de dois solos com elevados teores deste elemento. Foram coletadas amostras da camada superficial $(0$ a $10 \mathrm{~cm})$ de um typical dystrophic Lithic Udorthent - LU (Neossolo Litólico distrófico típico) e de um Humic Dystrudept - HD (Cambissolo Húmico alumínico típico) da região da Serra do RS, cultivados com parreirais que receberam aplicações sucessivas de produtos à base de $\mathrm{Cu}$. Foram determinados os teores de $\mathrm{Cu}$ solúvel em DTPA e pelo método Mehlich III, além do $\mathrm{Cu}$ trocável em $\mathrm{CaCl}_{2}$. A disponibilidade de $\mathrm{Cu}$ foi afetada principalmente pelo $\mathrm{pH}$ do solo. $\mathrm{O}$ extrator $\mathrm{CaCl}_{2}$ foi o que melhor se correlacionou com os teores de $\mathrm{Cu}$ em solos contaminados em função dos tratamentos aplicados. A adição de cama-de-frango não diminuiu a disponibilidade de $\mathrm{Cu}$ destes solos. Os teores de $\mathrm{Cu}$ total variaram entre 1.300 e $1.400 \mathrm{mg} \mathrm{kg}^{-1}$ nos dois solos. Considerando os teores totais de $\mathrm{Cu}$ nos solos, as frações "disponíveis", extraídas por DTPA, por $\mathrm{CaCl}_{2}$ e por Mehlich III representaram, em média, $35 \%, 0,20 \%$ e $63 \%$ do total de $\mathrm{Cu}$ presente no solo, respectivamente.

\section{REFERENCES}

Abreu, C.A., Abreu, M.F., Andrade, J.C. (2001b) Determinação de cobre, ferro, manganês, zinco, cádmio, cromo, níquel e chumbo em solos usando a solução de DTPA pH 7,3. In Análise química para avaliação da fertilidade de solos tropicais, eds B. van RAIJ, J.C. Andrade, H. Cantarella, J.A. Quaggio) pp. 240-250. (Instituto Agronômico: Campinas).

Abreu, C.A., Ferreira, M.E., Borkert, C.M. (2001a) Disponibilidade e avaliação de elementos catiônicos: Zinco e Cobre. In Micronutrientes e elementos tóxicos na agricultura, eds M.E. Ferreira, M.C.P. Cruz, B. van Raij, C.A. Abreu) pp. 125-150. (CNPq/FAPESP/POTAFÓS: Jaboticabal).

Barry, G.A., Chudek, P.J., Best, E.K., Moody, P.W. (1995) Estimating sludge application rates to land based on heavy metal and phosphorus sorption characteristics of soil. Water Research 29, 20312034.

Brun, L.A., Maillet, J., Hinsinger, P., Pepin, M. (2001) Evaluation of copper availability to plants in coppercontaminated vineyard soils. Environmental Pollution 11, 293-302.

Brun, L.A., Maillet, J., Richarte, J., Herrmann, P., Remy, J.C. (1998) Relationships between extractable copper, soil properties and copper uptake by wild plants in vineyard soils. Environmental Pollution 102, 151-161.

Camargo, O.A., Valadares, J.M.A.S., Dechen, A.R. (1982) Efeitos de pH e da incubação na extração do manganês, zinco, cobre e ferro do solo. Revista Brasileira de Ciência do Solo 6, 83-88.

Cantarella, H., Quaggio, J.A., Raij, B.van (2001) Determinação da matéria orgânica. In Análise química para avaliação da fertilidade de solos tropicais, eds B. van Raij, J.C. Andrade, H. Cantarella, J.A. Quaggio) pp. 173-180 (Instituto Agronômico: Campinas). 
C.E.C. (Commission of the European Communities) (1986) Council Directive on the protection of the environment, and in particular of the soil, when sewage sludge is used in agriculture. Official Journal of the European Communities L181, Annex 1A, p. 10.

Delas, J. (1963) La toxicité du cuivre accumulé dans le sols. Agrochimica.7, 258-288.

Deluisa, A., Giandon, P., Aichner, M., Bortolami, P., Bruna, L., Lupetti, A., Nardelli, F., Stringari, G. (1996) Copper pollution in Italian vineyard soils. Communications of Soil Science and Plant Analysis 27, 1537-1548.

Drouineau, G., Mazoyer, R. (1962) Contribution à l'etude de la toxicité du cuivre dans les sols. Annales Agronomique 13, 31-53.

ESTADOS UNIDOS (1996) Environmental Protection Agency. Method 3052: microwave assisted acid digestion of siliceous and organically based matrices (compact disc). Washington.

Flores, C.A., Fasolo, P.J., Potter, R.O. (1999) Solos: levantamento semidetalhado. In Vale dos vinhedos: caracterização geográfica da região, org. I. Falcade, F. Mandelli) pp. 87-137. (EDUCS: Caxias do Sul).

Flores Vélez, L.M., Ducaroir, J., Jaunet, A.M., Robert, M. (1996) Study of the distribution of copper in an acid sandy vineyard soil by three different methods. European Journal of Soil Science 47, 523-532.

Gupta, S.K., Aten, C. (1993) Comparison and evaluation of extraction media and their suitability in a simple model to predict the biological relevance of heavy metal concentrations in contaminated soils. International Journal of Environmental Analytical Chemistry 51, 26-46.

Jackson, M.L. (1964) Análisis químico de suelos. (Ediciones Omega: Barcelona).

Kabata-Pendias, A., Pendias, H. (1987) Trace elements in soils and plants. (CRR Press: Boca Raton).

Lindsay, W.L., Norvell, W.A. (1978) Development of a DTPA soil test for zinc, iron, manganese, and copper. Soil Science Society of America Journal 42, 421-428.

Lopes-Mosquera, M.E., Moiron, C., Carral, E. (2000) Use of dairy-industry sludge as fertilizer for grasslands in northwest Spain: heavy metal level in the soil and plant. Resource, Conservation and Recycling 30, 95-109.
Mehlich, A. (1984) Mehlich-3 soil test extractant: a modification of Mehlich-2 extractant. Communications in Soil Science and Plant Analysis 15, 1409-1416.

Moolenaar, S.W., Beltrami, P. (1998) Heavy metals in the environment. Heavy metal blances of an Italian soil as affect by sewage sludge and Bordeaux misture applications. Journal of Environmental Quality 27, 828-835.

Norvell, W.A. (1991) Reactions of metal chelates in soils and nutrient solutions. In Micronutrients in agriculture, eds J.J. Mortvedt, F.R. Cox, L.M. Shuman, R.M. Welch) pp. 187-228. (Soil Science Society of America: Madison).

Obrador, A., Rico, M.I., Mingot, J.I., Alvarez, J.M. (1997) Metal mobility and potential bioavailability in organic matter-rich soil-sludge mixtures: effect of soil type and contact time. The Science of the Total Environment 206, 117-126.

Pietrzak, U., McPhail, D.C. (2004) Copper accumulation, distribution and fractionation in vineyard soils of Victoria, Autralia. Geoderma 122, 151-166.

Silveira, M.L.A., Alleoni, L.R.F. (2003) Copper adsorption in tropical oxisols. Brazilian Archives of Biology and Technology 46, 529-536.

Silveira, M.L.A., Alleoni, L.R.F., Guilherme, L.R.G. (2003) Biosolids and heavy metals in soils. Scientia Agricola 60, 793-806.

Sims, J.L., Patrick, J.W.H. (1978) The distributions of micronutrient cations in soil under conditions of varying redox potential and $\mathrm{pH}$. Soil Science Society America Journal 42, 258-262.

Sposito, G. (1989) The chemistry of soils. (Oxford University Press: New York).

Stevenson, F.J., Ardakani, M.S. (1972) Organic matter reactions involving micronutrients in soils. In Micronutrients in agriculture, eds J.J. Mortvedt, P.M. Giordano, W.L. Lindsay) pp.79-114. (Soil Science Society of America: Madison).

Stevenson, F.J. (1994) Humus chemistry: Genesis, composition, reactions. (John Wiley: New York).

Received: December 02, 2005; Revised: August 10, 2006; Accepted: April 02, 2007. 